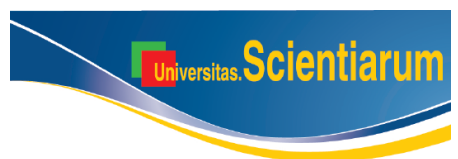

Disponible en línea en:

www.javeriana.edu.co/universitas_scientiarum

2011, Vol. $16 \bar{N}^{\circ}$ 3: 200-218

SICI: 2027-1352(201109/12)16:3<200:RHCRCSIC>2.0.TS;2-W

Invited review

doi: 10.11144/Javeriana.SC16-3.rohc

\title{
Review on hard coral recruitment (Cnidaria: Scleractinia) in Colombia
}

\author{
Alberto Acosta $^{1}$, Luisa F. Dueñas ${ }^{2}$, Valeria Pizarro ${ }^{3}$ \\ ${ }^{1}$ Unidad de Ecología y Sistemática, Departamento de Biología, Facultad de Ciencias, Pontificia Universidad Javeriana, Bogotá, D.C., Colombia. \\ Laboratorio de Biología Molecular Marina - BIOMMAR, Departamento de Ciencias Biológicas, Facultad de Ciencias, \\ Universidad de los Andes, Bogotá, D.C., Colombia. \\ ${ }^{3}$ Programa de Biología Marina, Facultad de Ciencias Naturales, Universidad Jorge Tadeo Lozano. Santa Marta. Colombia. \\ *laacosta@javeriana.edu.co
}

Recibido: 28-02-2011; Aceptado: 11-05-2011

\begin{abstract}
Recruitment, defined and measured as the incorporation of new individuals (i.e. coral juveniles) into a population, is a fundamental process for ecologists, evolutionists and conservationists due to its direct effect on population structure and function. Because most coral populations are self-feeding, a breakdown in recruitment would lead to local extinction. Recruitment indirectly affects both renewal and maintenance of existing and future coral communities, coral reef biodiversity (bottom-up effect) and therefore coral reef resilience. This process has been used as an indirect measure of individual reproductive success (fitness) and is the final stage of larval dispersal leading to population connectivity. As a result, recruitment has been proposed as an indicator of coral-reef health in marine protected areas, as well as a central aspect of the decision-making process concerning management and conservation. The creation of management plans to promote impact mitigation, rehabilitation and conservation of the Colombian coral reefs is a necessity that requires firstly, a review and integration of existing literature on scleractinian coral recruitment in Colombia and secondly, larger scale field studies. This motivated us to summarize and analyze all existing information on coral recruitment to determine the state of knowledge, isolate patterns, identify gaps, and suggest future lines of research.
\end{abstract}

Key words: recruitment, juvenile, coral, Scleractinia, structure, reef, Colombia, density, richness, monitoring.

\section{Resumen}

Revisión sobre el reclutamiento de corales duros (Cnidaria: Scleractinia) en Colombia. El reclutamiento, definido y medido como la incorporación de nuevos individuos (ej. juveniles de coral) a la población, es considerado en arrecifes coralinos como un proceso fundamental por parte de ecólogos, evolucionistas y conservacionistas debido a que determina de forma directa la estructura y función de las poblaciones. Además, debido a que la mayor parte de las poblaciones coralinas se auto-abastecen (self-seeding), fallas en el reclutamiento conducirían a extinción local. Indirectamente, el reclutamiento afecta la renovación y el mantenimiento de las comunidades coralinas presentes y futuras, la biodiversidad (efecto bottom-up) y por lo tanto, la capacidad de resiliencia del ecosistema arrecifal. Este proceso ha sido empleado como una medida del éxito reproductivo de individuos (fitness) y representa la etapa final del proceso de dispersión que conlleva a la conectividad poblacional. Es por lo anterior, que esta variable ha sido propuesta como un indicador del estado de salud de los arrecifes en áreas marinas protegidas y es un elemento fundamental para la toma de decisiones de manejo y conservación. Generar planes de manejo que propendan a minimizar impactos, rehabilitar y conservar los arrecifes del país es una necesidad que requiere en primera instancia de una revisión e integración de la literatura existente sobre reclutamiento de corales escleractínios en Colombia, al igual que estudios de campo a mayor escala. Lo anterior nos motivó a analizar y sintetizar la literatura existente con el ánimo de determinar el estado del conocimiento, extraer patrones, identificar vacíos y sugerir líneas de investigación.

Palabras clave: reclutamiento, juvenil, coral, escleractinia, estructura, arrecife, Colombia, densidad, riqueza, monitoreo. 


\section{Resumo}

Revisão sobre o recrutamento de corais pétreos (Cnidaria: Scleractinia) na Colômbia. O recrutamento, definido e medido como a entrada de novos indivíduos para a população (exemplo juvenis do coral), tem sido considerado como um processo fundamental pelos ecólogos, os evolucionistas e conservacionistas que trabalham em recifes de coral, ja que determina diretamente a estrutura e a função das populações. Além disso, dado que a maioria das populações de coral produz seus próprios juvenis (self-seeding), falhas no recrutamento levam à extinção local. Indiretamente, o recrutamento afeta a renovação-manutenção das comunidades de corais presentes e futuras, a biodiversidade (efeito bottom-up) e, portanto, da resiliência do ecossistema recifal. Este processo tem sido utilizado como uma medida de sucesso reprodutivo dos indivíduos (fitness) e representa o estágio final do processo de dispersão que leva a conectividade populacional. Pelo exposto, esta variável tem sido proposta como um indicador da saúde dos recifes nas áreas marinhas protegidas e é um elemento chave na tomada de decisões de gestão e conservação. Gerar planos de ação que tendem a minimizar impactos, recuperar e preservar os recifes do país é uma necessidade que requer, em primeira instância, uma revisão e integração da literatura existente sobre o recrutamento dos corais escleractíneos na Colômbia; assim mesmo, estudos de campo a escala maior. Isso levou a analisar e sintetizar a literatura existente com o objetivo de determinar o estado do conhecimento, abstrair padrões, identificar vazios e sugerir linhas de pesquisa.

Palavras-chave: recrutamento, juvenil, coral, escleractíneos, estrutura, recifes, Colômbia, densidade, riqueza, monitoramento.

\section{Introduction}

Colombia has approximately $2,900 \mathrm{~km}^{2}$ of reef areas (Figure 1), of which, 1,091 $\mathrm{km}^{2}$ have extensive reef cover, this represents less than $0.4 \%$ of the world's total reef surface (1). Of this total, only a very small part $\left(15 \mathrm{~km}^{2}\right)$ is found in the Pacific coast (i.e. Utría bay, Gorgona Island, Malpelo Island). However, the largest coral reefs in Colombia are found in the Caribbean, specifically, in the San Andrés, Providencia and Santa Catalina archipelago (77\%). Given that most of them are located on the oceanic platform their distribution is not uniform. The most extensive and representative areas in the Colombian continental platform are located in the Corales del Rosario and San Bernardo National Natural Park (PNNCRySB) (2). According to Díaz et al. (2), there are at least 26 coral reef areas in Colombia, each with a great diversity of landscape units (assemblages). Unfortuntely, in the last decades we have witnessed the loss of $30 \%$ of the world's coral reefs (3), including those in Colombia (4, $5)$. Coral cover has been affected by natural disturbances such as hurricanes (e.g. Hurricane Beta, which caused mild perturbations in Providencia and Santa Catalina islands in 2005) (6), bleaching that reached its highest intensity in 2005 and 2010 (7), disease (7), and the overgrowth of macroalgae (e.g. genera Halimeda, Lobophora, Dictyota) and sponges (Cliona spp.); additionally, human activities have also contributed to coral damage (overfishing, pollution, uncontrolled tourism, and sedimentation) (8).

Coral reef damage has become evident by its cover loss at a rate of $5-20 \%$ per decade (4), this due primarily to adult colony mortality (2). Accordingly, the reproductive effort has been reduced (given the smaller number of polyps) as well as recruitment and reef tridimensionality, affecting the viability of other groups such as fish and invertebrates negatively, as well as the dynamics of ecological processes (e.g. herbivory and predation). The latter implies that a decrease in or lack of coral recruitment causes a cascade effect (bottom-up) that alters the structure, state and dynamics of the ecosystem (9). The process of coral recruitment is defined as the incorporation of an individual into a population and occurs when larvae settles, endures metamorphosis (formation of a calcium carbonate skeleton), becomes a polyp, and the juvenile survives for a period of time (10). According to ecologists, the importance of this process is that it determines the renewal and maintenance of the structure of existing and future coral populations and reef communities at a local level; whereas, evolutionists claim it favors the increase of genetic variability in populations, and thus enhances adaptation to changing environments (11). Both the ecological and evolutionary approaches coincide on recruitment as a key attribute to achieve reef resilience.

Coral size influences the gamete producing capacity, therefore, the population's potential to reproduce sexually can be reduced if the size of the corals that constitute the population is also reduced (12). Consequently, if the coral population experiences partial mortality (loss of living tissue cover) there will be a reduction in colony size; as a result, the recruitment process will be affected as well as the capability of genetic population renewal by sexual reproduction.

Corals have the ability to renew their populations through sexual and asexual reproduction (fragmentation and fission), creating a defined structure of colony size class that ensures maximum population growth and its viability. The size and viability of a population is ultimately the result of a fine balance between the input (incorporation of new individuals to the population) and output (colony mortality) of individuals; 


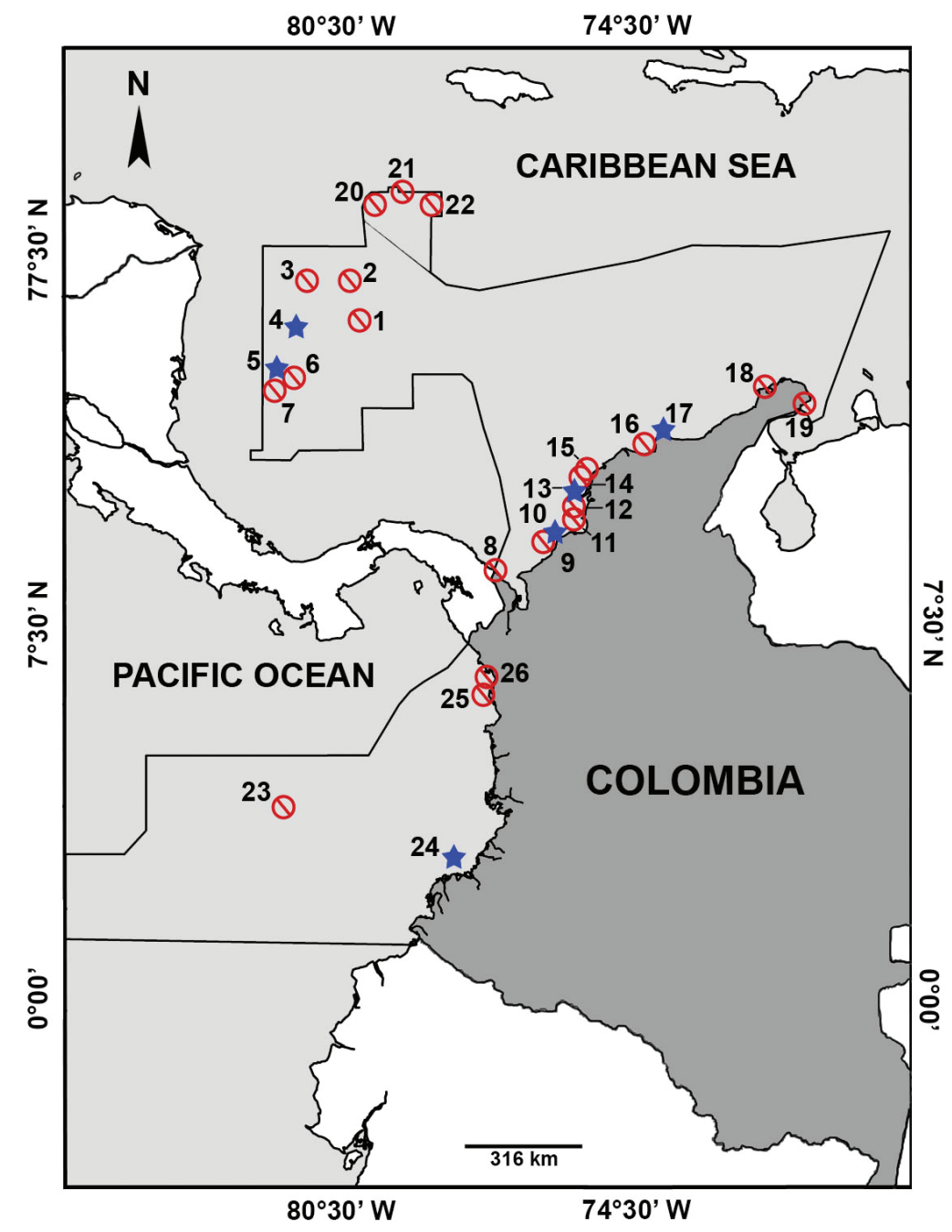

Figure 1. Location of the 26 reefs and coral formations in Colombia, according to Diaz et al. (2). 1-Roncador bank, 2-Serrana bank, 3-Quitasueño bank, 4-Providencia and Santa Catalina, 5-San Andrés, 6-Courtown key (Bolívar), 7-Albuquerque key, 8-Capurganá and Sapzurro, 9-Tortuguilla island, 10-Isla Fuerte, Bajo Bushnell and Burbujas, 11-San Bernardo island, 12-Bajo Tortugas, 13-Rosario islands, 14-Bajo Salmedina, 15-Isla Arena, 16-Ánimas bank, 17-Santa Marta and Tayrona park, 18-Portete bay, 19-Puerto López, 20-Serranilla bank, 21-Bajo Alicia, 22-Bajo Nuevo, 23-Malpelo island, 24-Gorgona island, 25-Utría cove, 26-Punta Tebada (2). $\star=$ Reefs with information on coral recruitment. $Q=$ Reefs without information on coral recruitment.

however, we infer that this balance has been shattered for the majority of species. For example, according to Alvarado and Acosta (13) the summation of high partial and total colony mortality in populations of Montastraea annularis, the low number of their colonies and fertile ramets, the species' low fecundity, and insufficient production of spermaries in areas highly degraded by natural and human impact, places the viability of the populations at risk. In consequence, the output exceeds the input of individuals (negative balance) affecting population structure and growth. A similar cascade of events has also been observed in other coral species such as M. faveolata, M. cavernosa and Porites asteroides in PNNCRySB reefs and in the Tayrona National Natural Park (PNNT) while following an eutrophication gradient (Alvarado et al. unpublished data). This is supported by the observations made on Colpophyllia natans in the PNNT (Pizarro et al. unpublished data).

When the number of juveniles being incorporated into the system (recruitment) is reduced, both the renewal 
of individuals and the recovery of the living coral tissue cover are impeded $(9,14)$. The outcome of this synergy is a simplification of the population size structure resulting from the loss of some size classes. It also affects functional aspects when the intrinsic rate of population growth is lowered to the point where it becomes negative $(r<0)$. Similarly, it causes, in time, strong oscillations in population size, reaching critical levels where any minor perturbation may result in the local extinction of the population. This may have been the case of Manicina areolata (15) in the seagrass beds of San Andrés Island; this species was affected through repeated massive bleaching caused by El Niño events. Another example occurring in less deteriorated reefs is the gradual reduction of $M$. annularis juveniles, a key reef building species in Caribbean reefs; such is also the case of Dendrogyra cilyndricus in Providencia Island (16). D. cilyndricus displays low recruitment rates and its reproductive colonies of large size continuously die or are fragmented as a consequence of human activities (16). The outcome is colonies of smaller size producing insufficient juveniles for population self-seeding, caused by a reduction of the average fertility in the population. This situation creates a circular process in which the decrease or absence of juveniles prevents the replacement of dying adult colonies and increases the risk of local extinction (15). As a result, low fecundity, low fertilization, and low larvae production and survival, affect the population structure (frequency distribution) and dynamics directly (natality and mortality rates), and indirectly, they affect the coral community, reef structures and function.

Cascade effects generated by low recruitment have been summarized as follows (8) by hindering the transition from juveniles to adults, the increase of coral cover prevented, and in turn the creation of three-dimensional reef (high rugosity), aggravated by the continuous effect of erosion (hydrodynamical and bioerosion) on the reef structure. As a result, the structural complexity and necessary habitat for the recruitment of invertebrates and fish species are reduced through time. And so, the lower abundance of herbivores decreases grazing intensity (in time and surface area) and increases algal cover, which causes a direct (i.e., competition for light and substrate) or indirect (by limiting the availability of settling surface) negative impact on the recruitment and survival of coral juveniles. This phenomenon has been observed in Isla Grande (PNNCRySB) where the reef system shows a phase shift from coral to algal in shallow areas under $12 \mathrm{~m}$ deep (16). The increase in algal cover has been widely documented in other Caribbean reefs, e.g., Jamaica (17). It seems this condition is caused by the lack of herbivores and the low quality of the water, which makes the development of coral communities unfavorable (e.g. high eutrophication and sedimentation).

The consequences of the bottom-up or chain reaction effect are local extinctions and biodiversity loss; this results in a simplified and unstable system with low resilience that will scarcely be able to return to its initial state (18). In reefs with these conditions, management actions to restore the system's structure and functioning may be very complex and costly; however, if actions are to be taken, local tensors must first be reduced (e.g., the effect of rivers) and the resistant species identified. For example, viability and dynamics of fish and coral depend mainly on the larval supply from the same self-seeding population, rather than the supply of larvae arriving from other populations via passive dispersal (21); therefore, management should be focused on minimizing human (fisheries, tourism, pollution) and natural impacts on habitat and on juvenile and reproductive individuals on a local basis. To do this, recognition of the factors that adversely affect the different size classes of the reef species we intend to use or preserve is paramount. Another costeffective management alternative is to rely on the high natural regeneration capacity of the system, which will certainly respond to disturbances with an increase in dominance of a few species of high tolerance. In this scenario, favoring population connectivity between reefs will facilitate natural recovery through a population rescue effect via dispersal. Having coral reef conservation as our main objective, it is important to monitor recruitment patterns and the system's rate of larval self-supply to achieve a better understanding of its natural recovery potential and to be able to predict the structure and dynamics of the reef under the effect of different tensors or disturbances.

Recruitment as a process first requires that reproduction and larval settlement occur (19). Although larval settlement and recruitment are terms often used interchangeably in literature, there is a difference between them. Biologically, larval settlement is the process in which mature larvae choose a place to settle on a natural or artificial substrate. The process is finalized when the larvae go through metamorphosis and become a polyp; in other words, they go from a pelagic state to a benthic state (19). Metamorphosis occurs when the larvae, after dispersal, synthesize and secrete calcium carbonate to build their skeleton, that is, septa and corallite (19). When the polyp is fully developed it is then called a recruit. During the larval phase the organisms are microscopic; in order to quantify their settlement and subsequent recruitment (a polyp or group of polyps), artificial tiles are used in lieu of natural substrates. These tiles are later removed and brought to the laboratory, where the coral species that have settled are counted under a stereoscope. In colonial organisms, once the recruit (also called juvenile) is fully formed (a polyp with 
septa, mouth and tentacles), it divides asexually (gemmation or fission) to create other module-polyps and make up the colony or new individual in demographic terms. Once the juveniles grow enough to be visible underwater (diameter greater than $2-5 \mathrm{~mm}$ ), the recruitment process (juvenile presence and density) can be quantified effectively, since it is then possible to observe the juvenile in situ as a new member of the population.

Juveniles are a direct measurement of recruitment. It is assumed that a large percentage of the population dies during the settlement and recruitment phases, before the individual becomes a visible juvenile, as well as during its maturation phase to become a reproductive adult, this is called post-settlement mortality (20). To achieve more accurate estimates of initial coral recruitment rates would imply developing new techniques to view juveniles smaller than $2 \mathrm{~mm}$ in diameter. In field studies the difference between settlement and recruitment is whether the juveniles are visible (recruitment) and can be quantified as new members of the population. Settlement requires aposteriori microscopic or stereoscopic examination of the tiles. Quantifying recruitment however is more laborious immediately following settlement (achieved with the use of artificial tiles or artificial substratum for colonization) than once the juvenile has grown onto the natural substrate. We recommend consulting other authors $(10,21-23)$ for further discussion regarding these two stages. For this review, we took into account all the studies focused on juvenile corals.

Juvenile corals were defined as an individual polyp (e.g. a solitary polyp such as Scolymia sp.) or a group of polyps visible to the naked eye $(\geq 2 \mathrm{~mm})$ that are not reproductive. Therefore, for each species, we considered the variation in colony size and their minimum reproductive size, this information has been reported in literature only for certain species $(20,24,25)$. Data from other species of a similar adult size category was used as reference criteria to establish a minimum reproductive size (Table 1) for species whose reproductive studies have not been conducted or published and, whose minimum reproductive size has not been reported. Like so, juveniles are defined as colonies under $4 \mathrm{~cm}$ in diameter for those species considered large in size, meaning species in which the adults reach an average diameter greater than $15 \mathrm{~cm}$, e.g. Montastraea spp., Diploria spp. and Siderastrea siderea, among others (20, $24-26)$. Similarly, juveniles are defined as colonies under $2 \mathrm{~cm}$ in diameter for small species, in which adults do not exceed an average diameter of $15 \mathrm{~cm}$, e.g. P. astreoides and Favia fragum (27). According to Chiappone and Sullivan (26), colonies greater than $4 \mathrm{~cm}$ are considered non-juvenile or adult in the majority of species, as they have reached reproductive maturity or partial gamete production.

\section{Generalities}

This review reveals that knowledge on scleractinia coral recruitment in Colombia is based mainly on gray literature (undergraduate and graduate works), mostly unpublished; therefore, the importance of preserving and compiling this scattered and unknown literature. The first work completed in Colombia on this topic relates to larval settlement on artificial tiles, it was completed by Pizarro (38) and was published in 2007 (39). The study presents population aspects on a spatial as well as a temporal scale for $D$. labyrinthiformis, $D$. strigosa and C. natans in San Andrés Island (39). However, it was Vidal et al. (27) who first proposed a sampling desing in Colombia to quantify the number of juvenile corals in situ.

Most Colombian coral recruitment studies have examined the community structure of juvenile scleractinian corals to answer three questions: 1 . which and how many species of coral are recruiting? 2. where are they recruiting? (Referring to reefs, optimal depths and habitat for recruitment); and 3. how much are they recruiting? The biotic variables mainly being quantified are composition, richness, abundance, density, and juvenile cover area. To categorize the juveniles observed in the coral assemblage, relative abundances per species have been calculated in order to identify species of: dominant juveniles ( $>100$ colonies), intermediate $(>10<$ 100 colonies) and rare juveniles ( $<10$ colonies). Similarly, the Importance Value Index (IVI) has been used, which is based on the frequency of appearances of juveniles from a given species among samples (repetitions) and the density, abundance or relative cover.

Juvenile health conditions have been evaluated quantitative and qualitatively. In the former, health conditions are assessed as partial or total mortality. In the latter, they are assessed as the presence or absence of disease, competition with other sessile organisms (e.g. algae, sponges, corals, etc.), and free substrate space where juveniles can potentially grow $(5 \mathrm{~cm}$ around the juvenile). Three studies were found regarding mortality $(39-41)$. The first one (39) evaluated the mortality of brain-coral juveniles (Diploria and Colpophyllia species) in San Andrés Island; the second (40) quantified the mortality rate of different juvenile species in reefs of PNNCR and SB; and the third one (41) also in San Andrés, studied the post-recruit mortality of $M$. annularis complex. The results of these studies suggest that six months is not enough time to evaluate the post-recruit mortality rate and that sample size (minimum number of individuals or tiles) is crucial to successfully compare dependent variables (e.g. abundance, richness, density) between depths or species, especially if these have different reproductive strategies. Pizarro et al. (41) found that mortality in the first stages of the settlement process increased with time. They also found that colonies 
Table 1

Classification of some juvenile corals based on their minimum reproductive size.

\begin{tabular}{|c|c|c|c|c|c|c|}
\hline \multirow[b]{2}{*}{ Species } & \multicolumn{2}{|c|}{ Juvenile size } & \multirow{2}{*}{$\begin{array}{c}\text { Adult } \\
\text { size } \\
(\mathbf{c m})\end{array}$} & \multirow{2}{*}{$\begin{array}{l}\text { Reproductive } \\
\text { Mode }\end{array}$} & \multirow{2}{*}{$\begin{array}{l}\text { Growth } \\
\text { Type }\end{array}$} & \multirow[b]{2}{*}{ Reference } \\
\hline & $<2 \mathrm{~cm}$ & $<4 \mathrm{~cm}$ & & & & \\
\hline Agariciaagaricites (Linnaeus, 1758) & & $\mathrm{X}$ & 100 & B & Encrusting & (28) \\
\hline A. lamarcki (Milne Edwards \&Haime, 1848) & & $\mathrm{X}$ & 200 & B & Plates & (29) \\
\hline A. tenuifolia (Lamarck, 1848) & & $\mathrm{X}$ & 100 & B & Leaf(29) & \\
\hline Colpophyllianatans (Houttuyn, 1772) & & $\mathrm{X}$ & 100 & S & Submassive & (30) \\
\hline $\begin{array}{l}\text { Dichocoeniastokesii } \\
\text { (Milne Edwards \&Haime, 1848) }\end{array}$ & & $\mathrm{X}$ & 50 & S & Submassive & (31) \\
\hline Diploriastrigosa (Dana, 1848) & & $\mathrm{X}$ & 100 & S & Submassive & (32) \\
\hline Faviafragum (Esper, 1788) & $\mathrm{x}$ & & 10 & B & Submassive & (32) \\
\hline Helioseriscucullata (Ellis \&Solander, 1786) & & $\mathrm{x}$ & 40 & B & Leaf(29) & \\
\hline Manicinaareolata (Linnaeus, 1758) & & $\mathrm{X}$ & 20 & B & Submassive & (33) \\
\hline Meandrinameandrites (Linnaeus, 1758) & & $\mathrm{x}$ & 100 & B & Submassive & (29) \\
\hline $\begin{array}{l}\text { Montastraeaannularis } \\
\text { (Ellis \&Solander, 1786) }\end{array}$ & & $\mathrm{X}$ & 200 & S & Massive & (32) \\
\hline M. cavernosa (Linnaeus, 1767) & & $\mathrm{x}$ & 200 & S & Massive & (30) \\
\hline M. franksii (Gregory, 1895) & & $\mathrm{X}$ & 200 & S & Massive & (34) \\
\hline Mussaangulosa (Pallas, 1766) & & $\mathrm{X}$ & 30 & B & Submassive & (29) \\
\hline Poritesastreoides (Lamarck, 1816) & & $\mathrm{x}$ & 60 & B & Massive & (24) \\
\hline P. porites (Pallas, 1766) & $\mathrm{X}$ & & 50 & B & Branched & $(25,33)$ \\
\hline $\begin{array}{l}\text { Scolymiacubensis } \\
\text { (Milne Edwards \&Haime, 1849) }\end{array}$ & $\mathrm{X}$ & & 10 & B & Submassive & (29) \\
\hline S. lacera (Pallas, 1766) & $\mathrm{X}$ & & 15 & B & Submassive & (29) \\
\hline Siderastrea radians (Pallas, 1976) & $\mathrm{x}$ & & 30 & B & Massive & (35) \\
\hline S. siderea (Ellis \&Solander, 1786) & & $\mathrm{x}$ & 200 & S & Massive & $(25,32)$ \\
\hline $\begin{array}{l}\text { Solenastreabournoni } \\
\text { (Milne Edwards \&Haime, 1948) }\end{array}$ & & $\mathrm{X}$ & & S & Massive & (29) \\
\hline $\begin{array}{l}\text { Stephanocoeniasp. } \\
\text { (Milne Edwards \&Haime, 1848) }\end{array}$ & & $\mathrm{X}$ & 30 & B & Massive & (36) \\
\hline $\begin{array}{l}\text { Madracis mirabilis } \\
\text { (Duchassaing\&Michelotti, 1861) }\end{array}$ & & $\mathrm{X}$ & 200 & B & Branched & (37) \\
\hline M. decactis (Lyman, 1859) & & $\mathrm{X}$ & 15 & B & Massive & (37) \\
\hline
\end{tabular}

The references pertain to the authors that identified the reproductive mode for each species. The average adult size was extracted from other sources. Reproductive modes: brooder (B), spawners (S).

smaller than $0.5 \mathrm{~cm}$ would have a greater mortality rate in comparison to larger sized juveniles. These findings suggests that the mortality rate during initial life cycle stages follow a normal curve, increasing mortality from larva settlement until the juvenile reaches a certain size (escape by size), then decreasing mortality as the individual reaches the minimum reproductive size.
The habitat or microhabitat of juvenile corals has also been studied $(42-45)$ and it has been described through a series of variables related to the presence or absence of juveniles in an area. For example, the geographic position of the coral reef can be related to the presence and degree of influence of large rivers (oceanic vs. continental) and the type of substrate colonized by the juvenile (natural: dead coral skeleton, rock, 
rubble, sand, or artificial: bottles, chains, tires); the spatial location of the juvenile with respect to light (exposed - direct light or cryptic - indirect or no light) and the relative light that reaches the juvenile; the inclination of the substrate on which the juvenile settles (horizontal, vertical or inclined); the presence and thickness of sediment layer surrounding the juvenile (no sediment, disperse, moderate - less than 1 $\mathrm{cm}$; and high - greater than $1 \mathrm{~cm}$ ) and the type of sediment according to its texture (clay/silt/sand).

Many of the previously mentioned dependent variables have been statistically related to different independent variables. For example, on a spatial level there have been comparisons on the horizontal scale, that is, between reefs, covering regional (hundreds of kilometers) and local scales (tens of meters or few kilometers); (45); whereas on a vertical spatial scale, there have been predominantly depth comparisons, whether considering the entire range of depth of the reef or only part of it. Three depth ranges have even been suggested for vertical comparison; shallow: from surface down to 8 $\mathrm{m}$; medium: between 10 and $16 \mathrm{~m}$; and deep: greater than $16 \mathrm{~m}(42,44-49)$.

Some juvenile-related variables have been used as a design factor to later contrast with dependent variables. Among them are population structure or juvenile distribution based on size classes according to maximum juvenile diameter (e.g. four categories; $0.1-1.0,1.1-2.0,2.1-3.0$, and $3.1-4.0 \mathrm{~cm})$. Other types of categorization are based on juvenile shape (e.g. branched, submassive, massive, leaf) the species' reproductive strategy (planulae brooding - internal fertilization; broadcast spawning - external fertilization). Equally, the existing correlation between the adult and the juvenile assemblage has been studied, using the density and cover of the two groups $(42,44)$.

\section{Sampling and Design}

The most common sampling size and method used in research of coral recruitment in Colombia, employs a total of $20 \mathrm{~m}^{2}$ per depth (1 x $1 \mathrm{~m}^{2}$ quadrats along $20 \mathrm{~m}$ line transects parallel to the coast; $42-49)$ or $30 \mathrm{~m}^{2}$ (50); however, researchers also employ other techniques such as fluorescent lights to quantify recruitment at night (this includes recruits smaller than $2-3 \mathrm{~mm}$, Zapata F., pers. com.). Without a doubt, the tagging of juveniles in situ continues to be a bottleneck that we must overcome in order to accurately estimate juvenile growth and mortality rates and to infer possible agents causing death, illness? This is of great importance given that compared to other stages of the life cycle, recruitment is the stage in which the majority of coral populations lose the highest percentage of individuals, making it essential to better quantify the population size and understand the population dynamics (19).

The sampling area for juvenile quantification in a reef has ranged between 94 and $180 \mathrm{~m}^{2}(42-49)$; meanwhile, for adult communities (in the same reef) it has ranged between 54 and $90 \mathrm{~m}^{2}(42-49)$. It is clear that the differences in sampling area size, between locations and regarding juveniles and adults, depends on the extension or depth of the reef and on the subjectivity of the researcher when selecting the design and/or number of replicates. The literature indicated that for some coral reefs in the Colombian Caribbean, sampling an area of $20 \mathrm{~m}^{2}$ is enough to include more than $80 \%$ of the juvenile community at a particular depth (27). Additionally, quantifying $10 \mathrm{~m}^{2}$ per depth seems to be enough to include the highest percentage of the adult coral community (51). This may explain why the structure of adult coral assemblages sampled simultaneously with that of the juveniles has a smaller sampling area. It is also a fact that because monitoring and quick evaluation of adult coral assemblages imply less effort, there is much more information available on adult corals (5).

As with other ecological studies, biases may exist. In the quantification of coral recruitment, the ability of the researcher to detect and recognize juveniles in situ is the predominant source of bias. The study by Dueñas (42) showed that when comparing different juvenile size classes the adequate evaluation of the category between $0.2-1.0$ $\mathrm{cm}$ is very difficult, resulting in it being underreported due to researcher bias (sight) or the technique being employed (45). As Babcock (52) indicates, it can also be difficult to evaluate small size categories because they have the highest mortality rates, which decrease as the juvenile grows. A good recruitment survey requires that the researcher not only know the habitats and microhabitats that the different species use for settlement (sometimes in cryptic areas), but also that he or she has the ability to identify recruits of a particular species or genus, even in the early stages of their development. This endeavor is complex without previous training in taxonomy, given that juvenile morphology not always resembles adult morphology.

In view of the implicit difficulty to arrive at a correct taxonomic determination, a visual guide was recently designed that identifies a large part of the juveniles of the different coral species in the Caribbean (53). This open access guide includes diagnostic characters visible in the field, which is why this tool is expected to make the arduous task of quantifying coral recruitment easier. Given the level of taxonomic uncertainty with certain genera (e.g. 
Mycetophyllia, Mussa, Isophyllastrea, Agaricia, Madracis among others) to date, it has been impossible to have a complete guide for the whole Caribbean. For this reason we call upon the scientific community of the Caribbean to help complement and improve the juvenile coral guide and to develop a homologous guide for the first stages of coral settlement (settled larvae on artificial tiles and in the process of metamorphosis). This initiative should be replicated for the species of the Colombian Pacific, which will be a much more consuming task given the great taxonomic complexity of the coral genera that inhabit the region (e.g. Pocillopora) (54).

\section{Horizontal spatial scale}

A similar number of coral recruitment studies have been conducted throughout the Colombian Caribbean in reefs considered in relatively good condition as well as those considered deteriorated (e.g. 44, 46 vs. 27, 42). It is suggested that coral recruitment is increased or decreased depending on its spatial location, where the composition of the species can also change according to reef conditions. However, the comparison between reefs is not straightforward; multiple variables must be considered, many of them particular to each area. Biotic and abiotic variables can affect the reef area (geology, bathymetry, topography, and hydrology), coral composition, abundance and cover per species and the area available for larval settlement, among others. The need for comparison forces researchers to standardize the different dependent variables used for the spatial contrasts (e.g. number of species $\mathrm{m}^{-2}$, density) or to use some variables as co-factors.

In the horizontal spatial scale the juvenile coral assemblage has been evaluated predominantly in the Caribbean, only recently, a recruitment project is being developed in the Colombian Pacific employing fluorescent lights and tiles (Figure 1). For this reason, this review is mainly focused on the results obtained from recruitment studies conducted in the Colombian Caribbean.

So far, only minimal fractions of the almost $2,900 \mathrm{~km}^{2}$ of reef areas have been sampled. In the Caribbean, the recruitment process has been evaluated in only two oceanic reefs of the Archipelago of San Andrés, Providencia and Santa Catalina, an archipelago that represents almost 77\% of the country's reef coverage. Additionally, eight reefs have been evaluated in the continental platform in Islas del Rosario and Isla Fuerte, within the PNNCRySB, which is the most extensive protected area of the continental platform. Some coastal fringing reefs have also been evaluated in Santa Marta (Punta Betín) and Chengue (PNNT). On the other hand, we still know nothing about coral recruitment in Utría and Isla Malpelo in the Colombian Pacific, while in La Azufrada (Isla Gorgona) an annual sampling on artificial plates reflects the absence of coral juveniles (54). This means that out of the 26 coral reef areas in Colombia (Figure 1), basic information on scleractinia recruitment exists only for seven (27\%). Moreover, given that the total reef area vs. sampled area ratio has not been considered, current studies do not represent the reality of the quantified Colombian reefs.

Although the majority of coral recruitment studies have been skewed towards the leeward side of the islands or continent where sampling is easier, some attempts have been made on the windward side, where winds and current are stronger. In windward, the quantification of settlement has been carried out for some species of the Diploria and Colpophillia genera, in the island of San Andrés (39), as well as for the entire juvenile community, in Isla Grande in the PNNCRySB (46). The only Colombian study that has compared recruitment between windward and leeward found a similar structure between both areas (50); however, it is possible that this process could be more effective towards the protected side (less hydrodynamics) as has been observed in artificial reefs in Dubai (55). Consequently, this hypothesis should still be corroborated, by comparing the two conditions (exposed and protected) in Colombian reefs. Furthermore, recruitment rates should be related to information on the local and regional hydrodynamics of the water mass. The dynamics include the speed and direction of the local and regional current during, and weeks after coral spawning, in years with different climatic events. Hydrodynamic studies would allow for inferences regarding the effect of the local currents on reef self-seeding and the effects of regional currents on the dispersal success of larvae coming from source reefs; this can be applied to the design and establishment of marine protected areas, and coral reef rehabilitation and restoration.

\section{Richness}

Juveniles of 31 coral species were found in continental reefs vs. 40 in oceanic reefs (gamma richness), where the juveniles reported belong to 21 genera (56). The diversity per reef (alpha richness) varied from 17 to 34 species, from 17 to 28 in continental reefs and from 30 to 34 in oceanic reefs (45). Juvenile coral richness (at the species and genus level) is greater in oceanic reefs than it is in continental reefs. However, this pattern is not confirmed when richness is standardized according to sample size. Standardized richness varies between 1 and 2.9 juvenile species per every $10 \mathrm{~m}^{2}$ of sampling area in continental reefs 
and $1.6-1.7$ juvenile species per every $10 \mathrm{~m}^{2}$ in oceanic reefs, with higher fluctuations in continental reefs. The ratio of average richness between continental and oceanic reefs is very similar, 1.80:1.65 juvenile species per $10 \mathrm{~m}^{2}$ of sampling area, respectively. Chengue bay (PNNT; 42) and Isla Fuerte reef (47) harbor a high number of juvenile coral species. Based on richness, Chengue bay would be in better conditions of conservation than continental reefs such as Isla Grande (PNNCRySB; 46) and Punta de Betín (Santa Marta; 44). As a consequence of large rivers and high human population density, continental reefs are exposed to a greater number of tensors than oceanic reefs (45). The closer the reef is to tensor sources, the higher the expectancy of low juvenile richness per area, but this is not the case (45). This contradiction should be scrutinized in order to understand the mechanisms that generate the observed richness patterns, which may be related to selective pressures and species tolerance (adaptation).

Higher species richness and diversity has been related to better resilience of the system when faced with disturbances (57); accordingly, the coral communities of some Colombian reefs, would be better suited to recuperate and better prepared than others to face disturbances or climate change. Based on richness results $(44,46)$, Islas del Rosario and Punta Betín would be less resilient than the rest of the Colombian reefs. Nonetheless, high species numbers is not enough; these amounts should be related to high density and species interactions in order to improve resilience.

\section{Density}

Oceanic island reefs exhibit higher juvenile coral density than those located on the continental platform (45), a difference of up to one order of magnitude. Density values fluctuate between 1.8 and 2.7 juveniles $\mathrm{m}^{-2}$ in continental reefs, and from 5.5 to 8.4 juveniles $\mathrm{m}^{-2}$ in oceanic reefs (45). The average juvenile density in PNNCRySB reefs and Punta Betín $\left(<2\right.$ juveniles $\mathrm{m}^{-2}$ ) has also been considered low with respect to other sampled locations in the Caribbean (24). The opposite is seen in San Andrés and Providencia (8.13 and 5.5 juveniles $\mathrm{m}^{-2}$ respectively).

The marked difference in density values between Colombian reefs could be explained by four factors: 1 . differences in intensity and frequency of disturbances; 2. differences in the live coral cover and therefore, in the reproductive effort; 3 . differences in post-recruitment mortality; 4. differences in species composition, since brooding species produce most offspring. The main factors inferred as responsible for post-recruitment coral mortality are the high rates of fine grain sedimentation (e.g. Isla Fuerte; 47) and the excess of macroalgae in the system (e.g. Halimeda sp. in Isla Grande; 46); however, there are no studies that show the degree of involvement of these factors in post-settlement mortality. Another explanation for the low number of juveniles in the continental platform could be the difference in live coral area. For example, Isla Fuerte is characterized by having the least live coral area $\left(28 \mathrm{~km}^{2}\right)$, in comparison with oceanic reefs such as San Andrés $\left(45 \mathrm{~km}^{2}\right)$ or Providencia $\left(124 \mathrm{~km}^{2} ; 2\right)$. Reduced live-tissue area makes Isla Fuerte have lower polyp number to contribute with a greater number of gametes and larvae for recruitment (58). In addition, disturbances whether natural or anthropic, are more frequent, intense and long lasting in the continental zone. These disturbances may be acting negatively and differentially, in an isolated manner or synergistically on some or all of the species of the community $(59,60)$, selecting those, which favor a brooding strategy in the short-term. Similarly, disturbances cause building coral populations to have less natural ability to replace dead individuals through reproduction; therefore, the tolerance and resilience to disturbances of coral populations in continental reefs, will be lower when faced with climate change. This will only be compensated by greater genetic diversity in continental reefs. Acosta and collaborators observed this for Palythoa caribaeorum (unpublished data) when comparing populations from San Andrés and Providencia (oceanic) vs. Isla Fuerte and Isla Grande (continental) through mt-DNA sequence analysis; however, this theory must still be examined in depth.

Coral density values suggest that recruitment on continental reefs, although existent, will not necessarily be enough for the natural recovery of many populations and of the reef as a whole. For this reason, it is important to establish management plans to eliminate or mitigate the disturbances to continental reefs, especially tensors that negatively affect coral survival and abundance at any stage of the life cycle and sexual reproduction output.

\section{Vertical spatial scale}

On the vertical spatial scale, most recruitment research has involved the reef's total depth range, from the surface to the beginning of the sandy bottom $(42,47-49)$ with the exception of some individual studies that have focused on two depth ranges, $2-5 \mathrm{~m}$ and $9-12 \mathrm{~m}$ (50) or only one depth range (27). In the latter, researchers only sampled the coral community structure with the highest development (27). Depth ranges in Colombian recruitment studies have fluctuated between 2 to $30 \mathrm{~m}$ in oceanic reefs $(27,39$, $48,49)$ and from 2 to $20 \mathrm{~m}$ in continental reefs $(42,46$, 
47, 50). These studies demonstrate notable differences in the vertical distribution of juveniles between oceanic and continental reefs (45). The differences in depth are largely mediated by the lack of available hard substrate for settlement (e.g. soft bottom), in addition to other abiotic conditions at great depths (e.g. light radiation), variables that could even exceed the physiological tolerance limit of larvae or juveniles.

Research has suggested that preferential or optimal depths exist, in which recruitment of the entire coral assemblage or for certain species is maximized (45). The vertical pattern observed in the coral assemblage is the combined result between past larval colonization, post-recruitment survival of juveniles, and natural selection. How selective pressure variables interact with depth should be investigated to truly infer larvae habitat selection and coral population's preference for a particular depth. However, some coral species seem indifferent to where settlement and recruitment occurs along the depth gradient, given their high plasticity and tolerance (e.g. light intensity, temperature, sediment, among others).

When conducting a coral recruitment study, sampling a narrow range of depths or a single depth is inadequate. The sampling design should take into consideration not only the ecological aspects of the reef but also the life history of the species. Monitoring only a segment of reef at a particular depth would be adequate once the optimal recruitment depth is ascertained for the different species and for the assemblage as a whole. This would allow an increase of the spatial sampling scale and a cost effective monitoring program. Similarly, optimal recruitment depths should be considered when conducting reef rehabilitation experiments (Pizarro et al., work in progress) or when implementing artificial reefs (e.g. Guajira), and before executing management actions. Taking into account optimal recruitment depth would minimize larval loss and would maximize juvenile survival.

\section{Density and richness}

As a common pattern, the hypotheses comparing juvenile density, richness and/or coverage between reefs (horizontal spatial scale) were not significant; while statistical comparisons of the same variables on a vertical spatial scale (depth) were. Therefore, the variation of density and richness of juveniles and adults is greater in its vertical component, within the reef, than between reefs. This pattern was observed while analyzing the results of various studies carried out in continental reef areas of Isla Grande $(40,46)$, Isla Fuerte (both part of the PNNCRySB; 47) and Santa Marta (44) and in oceanic reefs like San Andrés (48) and Providencia (49).

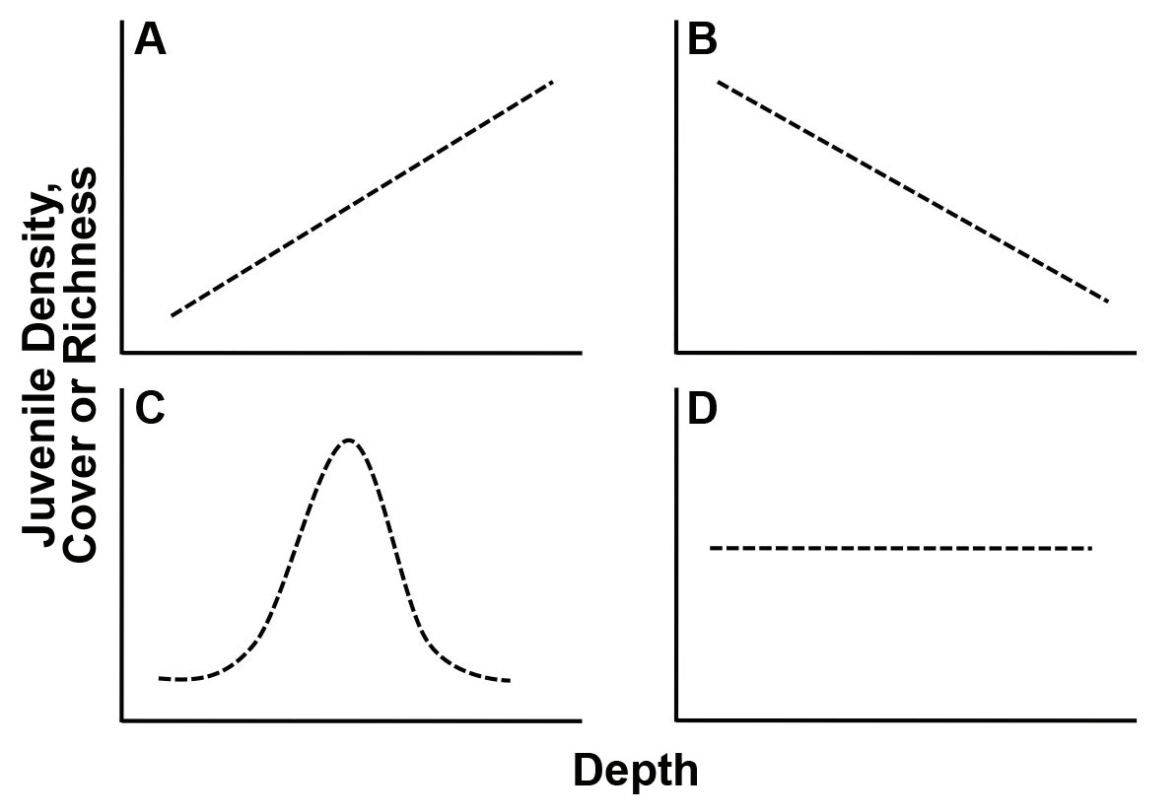

Figure 2. Coral recruitment patterns (juvenile density, richness and/or cover) with depth. A) Direct relationship, B) Inverse relationship, C) preferential depth or normal distribution, and D) no relationship. 


\section{Recruitment patterns}

There are various patterns of coral recruitment and depth (Figure 2), they are: 1. direct relationship between juvenile density, richness and/or cover and depth (Figure 2A.; 26, 61-64); 2. inverse relationship between juvenile density, richness and/or cover and depth (Figure 2B; 65); 3. greater juvenile density, richness and/or cover at a particular depth (preferential or optimal depth; 60,62,65-66), usually following a normal distribution, similar to what is suggested by the intermediate disturbance theory (Figure 2C); 4. juvenile density, richness and/or cover is not affected by depth, implying parity in juvenile density, richness and/ or cover in the vertical gradient due to random settlement, similar selective pressure between depths or both (Figure 2D; 24).

All the mentioned trends have been observed in Colombian reefs without establishing a definite pattern for quantified species and assemblages. However, two new patterns, not reported in the literature, seem to have emerged. In the first one, dependent variables (juvenile richness, density and cover) behave bi-modally with depth, and in the second a distribution with a positive skew is produced (Figure 3). The bi-modal pattern was found in Isla Grande, where Cárdenas (46) observed higher values between 2 and 4 $\mathrm{m}$ and maximum recruitment between 18 and $24 \mathrm{~m}$. The positive skew was found in Punta Betín, Santa Marta where $2-4 \mathrm{~m}$ depths differed from the rest, showing higher recruitment at $4 \mathrm{~m}$ (44). Future studies will indicate which pattern applies to each reef, which one is the dominant in Colombia and the factors and mechanisms that produced the observed patterns.

It is evident that a single pattern of recruitment with depth does not exist for continental reefs, possibly due to the differences in intensity, frequency and duration of natural and anthropic tensors to which reefs are exposed. For example, while Sepúlveda (47) found a normal density and richness distribution in Isla Fuerte and a peak of juveniles at 14 $\mathrm{m}$ in depth, Rodríguez (44) recorded a positively skewed distribution for Punta Betín, Santa Marta, and Cárdenas (46) at Isla Grande, found a bi-modal distribution of juvenile density, richness and cover with respect to depth (Figure 3). We hypothesized that the higher number of tensors that affect the continental reef is the reason why they exhibit most of the recruitment patterns observed. Selective pressures in those reefs should be explored to understand the underlying mechanisms that control recruitment.

As in the continental reefs, juvenile density, richness and cover were different between depth ranges in oceanic reefs in San Andrés (48) and Providencia (49). The results suggest a range of preferential depth for recruitment between 10 and $16 \mathrm{~m}$, revealing a normal distribution of the variables with depth (Figure 2C). The response of these variables to depth was the same for adult corals. This can be explained by Connell's (67) theory of intermediate disturbance, where

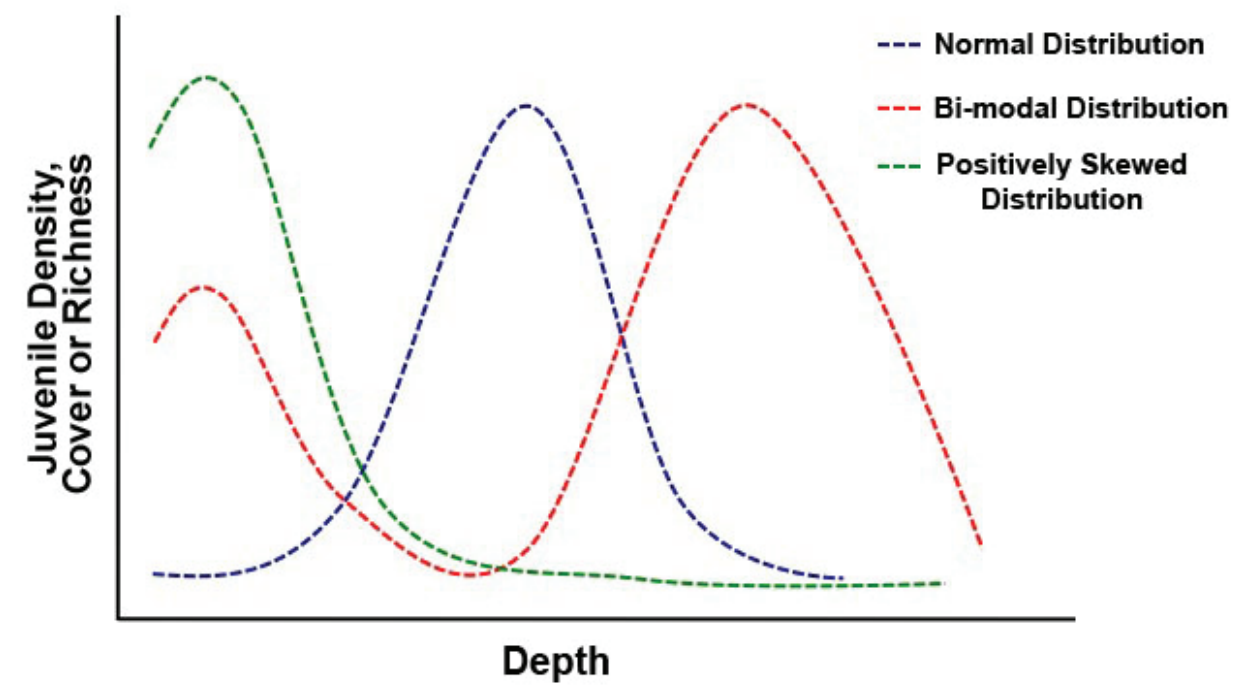

Figure 3. Coral recruitment patterns (juvenile density, richness and/ or cover) with respect to depth. A normal distribution of variables is shown and two deviations from this distribution: bi-modal and positively skewed distribution. 
in shallow and deeper zones, high intensity biotic and abiotic tensors exist that restrict the survival of most juvenile and/ or adult coral to intermediate zones, while reducing the richness and cover to only a few resistant species at extreme depths. Despite having a defined and common recruitment pattern for oceanic reefs, information regarding the abiotic (physical-chemical) and biotic (interactions) variables that explain the normal distribution is still unavailable. The study of biotic and abiotic variables with depth would also help us characterize and understand the specific factors that control dispersal.

In addition to the preferential and bi-modal depth patterns, a direct relation between juvenile density, richness and/or cover with depth was also found (Figure 2A). The density values observed in San Andrés by Pizarro et al. (39) while working with brain corals, suggests that as depth increases, juvenile density also increases. This finding has also been reported for other places in the Caribbean (e.g. reefs in Florida) (26), and in the Great Barrier Reef in Australia $(62,68)$.

Despite having three significant patterns related to depth, what is evident from the existing information is that at shallow depths (less than $10 \mathrm{~m}$ ), recruitment is very low for both oceanic and continental reefs. The causes for this pattern are still unknown but are possibly related to high light radiation, high hydrodynamics (waves), low salinity (e.g. Magdalena: 29 UPS), intense grazing, pollution (organic particles in suspension, oil, heavy metals, pesticides, insecticides among others), and larvae physiology and behavior. The combination of these factors should be explored in order to attribute them the mortality of gametes, larvae and juveniles in shallow areas. The exception is unquestionably Punta Betín, Santa Marta (44), where the high sedimentation rates in medium and deep zones make shallow depths the only option for recruitment and survival.

No evidence of the relationship of recruitment and depth was found in Chengue bay (PNNT; 42) and PNNCRySB (40) (Figure 2D). According to Dueñas (42), similar juvenile frequency with respect to depth can be explained by random larvae settlement and/or by selective factors displaying similar intensity along the vertical gradient, thus eliminating equal number of juveniles. It has already been documented that random settlement could be caused by the negative effects of pollutants on larvae sensors. Another possible explanation is that natural selection forces display a higher intensity in zones where settlement is greater, making the frequency of juveniles equal to zones with lower recruitment. All these possibilities could cause a homogeneous distribution of coral juveniles on the depth gradient.

\section{Coral zonation}

The zonation of adult corals species in coral reefs has been well documented $(69-71)$. Likewise, studies have been conducted on how juvenile coral species generate a vertical zonation $(72-74)$. Coral zonification has been associated with physical factors such as wave and current energy, desiccation, light and substrate availability, temperature and sedimentation, among others. Research results linking juvenile and adult zonification vary greatly, some find no correlation between them $(72,73)$ whereas others do (74).

It appears that species of the juvenile coral assemblages in Colombia, display marked zoning, since they use specific zones of the reef, whether shallow, medium or deep. For example, Scolymia spp., A. lamarcki and Acropora palmata juveniles select or are restricted to a particular depth, presenting high or low relatively abundance, respectively (42). On the other hand, juveniles of some species are represented along the entire depth gradient either with high (M. cavernosa, D. strigosa, M. decactis, A. agaricites, $P$. astreoides) or low densities ( $F$. fragum, M. faveolata, $D$. clivosa). A similar pattern is present in adult corals with depth. As indicated by Zlatarsky and Martínez-Estalella (75) the range of vertical distribution for most coral species in the Caribbean is very broad, suggesting that a good proportion of the coral assemblage is not highly specific and could therefore adapt and tolerate different variables that change with depth (light, temperature, pressure) during its life cycle (juvenile, adult). This theory could also be corroborated on the horizontal gradient (latitude, longitude), by observing the broad spatial distribution of a species, present within a wide spectrum of environmental conditions occurring in the different reefs. It is important to encourage research that explores the qualitative (presence and absence) and quantitative (density) relationship between juveniles and adults, as this has implications for the management given to certain zones (depths) of the reef. And so, adults of a species present in a reef zone, depend on recruitment and consequently on the supply of juveniles to replace them when they die; this is necessary to continue the long-term 3D development of the reef (3D) at that particular depth. Meanwhile, larvae of some coral species require the presence of adults of the same species or congeners, to settle, or readily settle close to the parent (brooding species), in order to experience the same habitat in which the adults have successfully survived. In-depth research on the adult-juvenile relationship with depth and the mechanisms involved will help us better understand the reef. 


\section{Temporal scale}

On the temporal scale, we found that coral recruitment studies have been conducted between 2003 and 2010. Most of them have quantified juvenile structure only once in a year. Only two studies have monitored variables for short periods of time (months to a year), to evaluate settlement or post-recruitment mortality $(39,50)$.

Since monitoring of juveniles has been minimal, greater emphasis should be provided to the temporal scale of the phenomena of settlement and recruitment to understand and measure the actual effect of reproductive effort and fitness in populations. A method for this is to use molecular techniques that allows us to estimate how many of these new genotypes, juveniles, product of sexual reproduction, are similar to the parent (adult colonies). This could provide an indication not only of the reproductive success of the species, but their potential for natural regeneration, capacity for adaptation, and maintenance of population, species and ecosystem diversity.

\section{Phase shift}

The phase shift hypothesis or "community shift" has been proposed by different researchers for other Caribbean reefs $(61,66,76)$, where spawning species are being replaced by brooding species. This replacement is indicated by the low and high frequencies of juveniles, respectively, and their ability to colonize empty substrates left by brooding species (77). Guzmán and Guevara (76) claim that Agaricia spp. and Porites spp. are replacing reef-building species such as Montastraea sp. and Acropora sp. in the Caribbean.

As opposed to those corals that release gametes, juvenile species with a brooding strategy dominate most of the reefs studied in Colombia (except in Punta Betín). Differences in density can triple or even reach an order of magnitude. An example of this is the Agaricia genus (especially A. agaricites), which presented the greatest frequency, density and relative cover of juveniles in oceanic reefs, while other species of the Agaricia genus and species of Porites (especially P. astreoides) presented high values in continental reefs (45). This result suggests that coral recruitment by brooding species (Agaricia spp. and $P$. astreoides) has proved dominant in relation to broadcast species. This is consistent with previous findings $(24,46$, 78) in places with high levels of nutrients and sedimentation. Higher density may be the result of the life history of these genera, that have: high reproduction, direct development, large larvae, rapid settlement along the depth gradient (high tolerance or plasticity), settlement close to the parent (spatial autocorrelation with the parent), stunted growth, short life cycle and high colony mortality rates $(28,46,47)$.

There is a trend where, in some Colombian Caribbean reefs, adult corals of the Montastraea, Colpophyllia (79), Diploria and Siderastrea genera have low recruitment and are being replaced by juveniles of the Agaricia, Porites, Scolymia, Helioseris, Dichocoenia and Favia (45) genera. Different causes have been proposed to explain this tendency. For example, the low number of juveniles of the genus Montastraea observed in Colombian continental reefs could be related to its low cover of adults (51) and its low fertility (13). Other tensors, such as the thick layer of clay-silt in Isla Fuerte (47), may be interfering with substrate recognition and settlement by the larvae (80). Similarly, high nutrients, macroalgae proliferation (46) and high sedimentation in Isla Grande (PNNCRySB) are impeding the establishment of many broadcast species and reducing the survival of juveniles because of over-growth. Literature indicates that species that are long-lived, slow growing and spawners, have reproduction cycles every few years or decades and can therefore take over a century to recover (15); this favors species with contrasting life strategies. Other explanations for the high representation of brooding species in some reefs cannot be discarded, for example, that Agaricia spp. and other brooder species have always been important to the coral assemblage, or that the replacement process of life history (brooder vs. broadcast) has been taking place for several decades.

At present, a generalization cannot be made in Colombia asserting that long-lived species (spawners) in the coral community are being replaced by short-lived species (brooders), as there are no monitoring programs or studies with an adequate time scale to attest the change. Also, in some reefs, the corals that have been dominant as adults for decades (genera Montastraea, Sideratrea, Agaricia, Porites, Helioseris) are the same ones that dominate today as juveniles. Besides that, a high representation of juveniles of M. cavernosa, S. siderea, S. cubensis and D. strigosa, broadcast species, are observed in Chengue (42) and Punta Betín (44).

Demonstrating that long-lived species (with juvenile density and richness) are being replaced by short-lived species would require tagging and monitory assessments of juveniles over time to quantify mortality rates by species and demonstrate replacement between life history strategies. Evidence of that change could represent a loss of reef tridimensionality and biodiversity (9). 


\section{Dependence between recruitment and habitat}

According to Bernal and collaborators (43), A. tenuifolia and $A$. lamarcki juveniles exhibited dependence on physical and biological extrinsic factors of the habitat on a macro and micro-scale. More than $70 \%$ of A. tenuifolia juveniles depended statistically on their location in continental reefs, in microhabitats with silt-clay sediment and on the direct interaction with macroalgae (43). On the other hand, $91.4 \%$ of A. lamarcki juveniles depended on substrates without accumulated sediment, oceanic reefs and exposed substrates (direct light; 43). The $A$. agaricites, $H$. cucullata, $P$. astreoides, $P$. porites, $F$. fragum, $M$. cavernosa and $S$. siderea juveniles were frequently found under the majority of the conditions of the quantified habitats (tolerant). They displayed high dependence on the availability of free space for growth, the type of reef and type and quantity of accumulated sediment (43). It is recommended that research related to the use, selection and habitat preference of corals be conducted, to fully understand the conditions and resources necessary to increase the likelihood of their survival and the effectiveness of their reproduction as well as to effectively innovate adaptive management, actions based on biological knowledge, to promote coral reef rehabilitation.

\section{Adult - juvenile richness and density relation}

Studies show that the richness of juvenile corals is inferior to that of adult corals (45). Similarly, the density of adults (3.95.8 adults $\mathrm{m}^{-2}$ ) surpassed that of juveniles in continental reefs $\left(1.8-1.98\right.$ juveniles $\left.\mathrm{m}^{-2}\right)$, when quantified simultaneously. Assumably, a reef in good condition should have greater or equal richness of juveniles and adults, given that recruitment is the combination of self-seeding (existing species) and larvae of new species from other source reefs. High richness is desirable because it increases the ecosystem's resilience. Furthermore, a greater or equal density of juveniles and adults would be expected for each species, creating a positively skewed size class structure. This pattern is indicative of population growth and an increase in the probability of metapopulation or species persistence. Contrarily, the studies suggests a breakdown in the stages prior to settlement and during recruitment that generate a lower richness of the coral assemblage and less juvenile density with respect to the ideal for each coral population in reefs of the Colombian Caribbean. As a result, the richness of juveniles : richness of adults ratio, and density of juveniles : density of adults ratio, could eventually be used in monitoring systems as an indicator (ideal $\geq 1$ ) of the system's capacity for natural renewal, of its resilience and population viability.

\section{Suggestions and possible questions}

The lack of information on coral recruitment in Colombian reefs and within each reef (exposed and protected zones) is evident. It is imperative that government entities, universities and NGOs make a combined effort to raise funds that will allow the acquirement of greater knowledge regarding recruitment, to make appropriate management decisions based on scientific information.

If the number of species (richness) is used as criteria for conservation (i.e. definition of protected areas), it is important to find processes and mechanisms that explain the number of coral species in continental reefs, compared to oceanic reefs or the weak correlation between richness of adults and juveniles. Another priority is estimating the beta richness to determine, over time, the species turnover of a reef and its shift, to address the possible transformation of the community ("community shift").

Monitoring recruitment in each reef is necessary to estimate birth and survival population rate; this is also a key measurement in the modeling of population dynamics and to calculate the risk probability of local extinction and population viability.

Minimizing anthropic effects is urgent (i.e. nutrification, sedimentation, pollution, reduction in salinity), because they negatively affect key processes in the first stages of the species' life cycle. Additionally, it is paramount to research the factor associated with the natural recovery of the system, to understand the effect of natural phenomena in processes such as adult survival, growth, reproduction, and fitness.

Because habitat and microhabitat determine what, when, how much and where recruitment for each coral species takes place (reef, depth and optimal time), the monitoring of coral juveniles on greater spatial (reefs and depths) and temporal scales (throughout the year and in years with different climate events) is recommended, as well as studying the physical and biological factors that facilitate settlement, recruitment and the survival of juveniles.

It is necessary to define what would be the habitat preference for coral species (depth) and identify the factor or set of factors (resource or condition) that determines use and selection $(81,82)$. This would help to explain patterns of recruitment with depth and would serve reef rehabilitation purposes. 
Both experimental and in situ studies are necessary to demonstrate whether physical or biological factors determine the spatial distribution (horizontal, vertical), composition, richness and density of juveniles, or whether if it is an entirely random process. For example, a question could be: Are $A$. tenuifolia juveniles really more resistant to high sediment rates than juveniles of other species?

The production of chemical substances by benthic organisms is one of the factors that most influences recruitment, but it has been ignored in studies conducted in Colombia. These chemicals serve as signals that activate planulae settlement by initiating morpho-physiological changes (83). Some of the substances identified are produced by red encrusted coralline algae (CCA; 77) and peptides produced by communities of bacteria (83). Morse and collaborators (77) found that the CCA activates the settlement of larvae of dominant species in the shallow reef, so this increases the importance of limestone algae and their role in the maintenance of the reefs. Contrarily, lwako and collaborators (83) found that the concentration of peptides affects recruitment inversely (decreasing from 100 to $0 \%$ ). This result may explain why most of the juveniles quantified in Colombia were not associated with red algae. Unfortunately, the information available globally on these substances is limited and apparently specific so it is necessary to develop projects that increase knowledge about the chemical signals that trigger or block biological processes (early stages of the life cycle).

It is also important to generate in situ and experimental evidence on whether the community is being replaced by juveniles of brooding species at the expense of broadcast species, and predict the consequences of this replacement on local and regional biodiversity, and on the generation of goods and services provided by the coral reef ecosystem (e.g. fisheries, protein sources, and tourism).

The coral reef ecosystems on our coasts and islands are of the few reef remanents in relatively good conservation conditions in the Tropical Eastern Pacific. This makes it imperative that the lack of knowledge on coral recruitment in the Colombian Pacific, reflected in this review, be corrected in the following years.

\section{Conclusions}

The analysis of coral recruitment in Colombian reefs indicates that existing information is recent, mostly unpublished and is basically on the structure of the juvenile community and only tangentially about their dynamics. In the spatial scale results are insufficient in both protected and unprotected areas, in windward locations, and particularly in the Colombian
Pacific. The pattern that emerges is that juvenile density is higher $(2-3$ times) in oceanic reefs than in continental reefs (even lower in degraded systems); however, this pattern is reversed when using the standardized juvenile richness. Juvenile richness and density varies more in the vertical (depth) than the horizontal component (reefs), and is minimal in shallow depths $(<10 \mathrm{~m})$ for almost all the reefs studied. On the depth gradient, greater efforts are needed to define recruitment patterns of each reef and identify the optimal depth for recruitment and juvenile survival. Status indicators such as the juvenile vs. adult coral-richness ratio and coral-density ratio suggest little effectiveness in the process of sexual reproduction and in the management of these reefs towards protecting the existing coral populations and biodiversity. It also suggests low reef connectivity, as a lower richness of juveniles than adults was observed at each reef (similar composition) as well as the absence of new recruited species from a different reef source. The information indicated low resilience of the reef ecosystem to current and new disturbances that may be caused by climate change, particularly in continental reefs.

Because of the lack of evidence it cannot be concluded whether a community shift is occurring in some reefs of the Caribbean, since in most Colombian reefs the broadcast species (i.e. genera Montastraea, Colpophyllia, Diploria and Siderastrea) are more abundant than brooding species (Agaricia spp. and Porites spp.). And so, understanding the colonization process and survival dynamics of juveniles requires the creation of a national monitoring program (i.e. juvenile tagging).

We have concluded that the recruitment of juvenile $A$. tenuifolia and A. lamarcki depends on specific habitat factor combinations, both physical and biological, which have been quantified on a macro $(\mathrm{km})$ as well as micro $(\mathrm{cm})$ scale, but no studies have been conducted on the effects of chemical signals. Nonetheless, most other dominant coral species present broad tolerance to various habitat factors.

Knowledge limitations regarding settlement and recruitment in Colombia are a result of the inexistence of: identification keys (i.e. Pacific), methods for recording and monitoring very small juveniles, information to relate biotic and abiotic variables (currents, habitat availability and quality), and experimental research, among others.

Future studies should examine the rates of reef self-seeding, the success of dispersal, measured as the rate of immigrants originating from other source populations, dispersal strategies for species of different life histories (according to morpho physiological and behavioral adaptations), the dispersal kernel to infer population connectivity, habitat availability, 
and the effect of these factors on demography, spatial distribution, connectivity and genetic structure of the species responsible for maintaining the reef ecosystem. Equally, communication among scientists and those responsible for managing resources should be improved to achieve an effective transfer of acquired knowledge and apply it to action plans within an adaptive management perspective in which management receives feedback from scientificallyderived information. Because of its importance, the concept of recruitment should be explicitly incorporated into the country's environmental policies.

\section{Acknowledgements}

We would like to thank Gypsy Español of Traducciones Tecnicas T\&T (HYPERLINK “mailto:gd.traduccionestyt@ gmail.com"gd.traduccionestyt@gmail.com) and anonymous reviewers for their valuable comments"

\section{Financial support}

We thank the Vicerrectoría Académica of the Pontificia Universidad Javeriana for funding the research on coral recruitment in the Colombian Caribbean. (Proposal ID 0000417).

\section{Conflict of interests}

This review does not generate any conflicts of interest. The unpublished information cited in this review is released with the permission of the authors.

\section{References}

1. Spalding M, Ravilious C, Green E, World Atlas of Coral Reefs, ed., University of California Press, Berkeley, USA 2001, 424p.

2. Díaz JM, Barrios LM, Cendales MH, Garzón-Ferreira J, Geister J, López-Victoria M, Ospina GH, ParraVelandia FP, Pinzón J, Vargas-Angel B, Zapata FA, Zea S, Áreas coralinas de Colombia, ed., INVEMAR, Serie Publicaciones Especiales, Santa Marta, Colombia 2000, $176 \mathrm{p}$.

3. Pandolfi JM, Jackson JBC, Baron N, Bradbury RH, Guzman HM, Hughes TP, Kappel CV, Micheli F, Ogden JC, Possingham HP, Sala E. Are U.S. Coral Reefs on the Slippery Slope to Slime?, Science 2005307 (5716): 1725-1726.

4. Martínez S, Acosta A. Cambio temporal en la estructura de la comunidad coralina del área de Santa Marta- Parque nacional Natural Tayrona (Caribe Colombiano), Boletín de Investigaciones Marinas y Costeras 2005; 34: 161-191.
5. Rodríguez-Ramírez A, Reyes-Nivia MC, Zea S, NavasCamacho R, Garzón-Ferreira J, Bejarano S, Herrón P, Orozco C. Recent dynamics and condition of coral reefs in the Colombian Caribbean, Revista de Biología Tropical 2010; 58 (Suppl. 1): 107-131.

6. Rodríguez-Ramírez A, Reyes-Nivia MC. Evaluación Rápida de los Efectos del Huracán Beta en la Isla Providencia (Caribe Colombiano) Boletín de Investigaciones Marinas y Costeras 2008; 37 (1): 217-224.

7. Navas-Camacho R, Gil-Agudelo DL, Rodríguez-Ramírez A, Reyes-Nivia MC, Garzón-Ferreira J. Coral diseases and bleaching on Colombian Caribbean coral reefs, Revista de Biología Tropical 2010; 58 (Suppl. 1): 95-106.

8. Garzón-Ferreira J, Díaz JM. The Caribbean coral reefs of Colombia, in Cortés J, (Eds). Latin American coral reefs. Elsevier Science B.V., Amsterdam, The Netherlands, 2003, p. 275-301.

9. Mumby PJ, Steneck RS. Coral reef management and conservation in the light of rapidly-evolving ecological paradigms, Trends in Ecology and Evolution 2008; 23: 555-563.

10. Todd CD. Larval supply and recruitment of benthic invertebrates: do larvae always disperse as much as we believe?, Hydrobiologia 1998; 375/376: 1-21.

11. Porter JW, Tougas JI. Reef ecosystems: threats to their biodiversity, Encyclopedia of Biodiversity 2001; 5: 73-95.

12. Soong K. Colony size as a species character in massive reef corals, Coral Reefs 1993; 12: 77-83.

13. Alvarado EC, Acosta A. Fertilidad y fecundidad de Montastraea annularis en un arrecife degradado, Boletín de Investigaciones Marinas y Costeras 2009; 38 (2): 91108.

14. Bak RP, Meesters EH. Coral population structure: the hidden information of colony size-frequency distribution, Marine Ecology Progress Series 1998; 162: 301-306.

15. Hughes TP, Tanner JE. Recruitment failure, life histories, and long-term decline of Caribbean corals, Ecology 2000; 81: 2250-2264.

16. Navas GR, Moreno-Forero SK, Solano OD, Díaz-Pulido G. Ensamblajes Arrecifales Epil[ticos del Coral Acropora palmata Muerto, Isla Grande, Islas del Rosario, Caribe Colombiano, Caribbean Journal of Science 1998; 34 (12): 58-66.

17. River G, Edmunds PJ. Mechanisms of interaction between macroalgae and scleractinians on a coral reef in Jamaica, Journal Experimental Marine Biology and Ecology 2001; 261: 159-172.

18. Done TJ. Phase shifts in coral reef communities and their ecological significance, Hydrobiologia 1992; 247: 121-132. 
19. Richmond RH. Reproduction and recruitment in corals: critical links in the persistence of reefs, in Birkeland C, (Eds). Life and Death of Coral Reefs. Chapman \& Hall, New York, 1997, p. 175-197.

20. Harrison PL, Wallace CC. Reproduction, dispersal and recruitment of scleractinian corals, in Dubinsky Z, (Eds). Ecosystems of the world. Coral Reefs. Elsevier, Amsterdam, 1990, p. 133-207.

21. Connell JH. The consequences of variation in initial settlement vs. post-settlement mortality in rocky intertidal communities, Journal of Experimental Marine Biology and Ecology 1985; 93 (1-2): 11-45.

22. Gosselin LA, Qian P-Y. Early post-settlement mortality of an intertidal barnacle: a critical period for survival, Marine Ecology Progress Series 1996; 135: 69-75.

23. Caley MJ, Carr MH, Hixon MA, Hughes TP, Jones GP, Menge BA. Recruitment and the local dynamics of open marine populations, Annual Review of Ecology And Systematics 1996; 27: 477-500.

24. Bak RP, Engel MS. Distribution, abundance and survival or juvenil hermatypic corals (Scleractinia) and the importance of life history strategies in the Parent Coral Community, Marine Biology 1979; 54: 341-352.

25. Richmond RH, Hunter C. Reproduction and recruitment of corals: comparisons among the Caribbean, the tropical Pacific and the Red Sea, Marine Ecology Progress Series 1990; 60: 185-203.

26. Chiappone M, Sullivan KM. Distribution, abundance and species composition of juvenile scleractinian corals in the Florida reef tract, Bulletin of Marine Science 1996; 58 (2): 555-569.

27. Vidal A, Acosta A, Villamil C. Composición y densidad de corales juveniles en dos arrecifes profundos de San Andrés Isla, Caribe colombiano, Boletín de Investigaciones Marinas y Costeras 2005; 34: 211-225.

28. Van Moorsel G. Reproductive strategies in two closely related stony corals (Agaricia, Scleractinia), Marine Ecology Progress Series 1983; 13: 273-283.

29. NSU, NCRI. CARIBBEAN CORAL SPAWNING TABLE. http://www.nova.edu/ncri/research/a21/caribbean_coral_ spawning_table.pdf. Feb. 03

30. Steiner SCC. Spawning in scleractinian corals from SW Puerto Rico (West Indies). Bulletin of Marine Science 1995; 56: 899-902.

31. Hoke SM, Colley SB, Feingold JS. Sexual reproduction in the elliptical star coral, Dichocoenia stokesi, MilneEdwards and Haime, C. Cnidaria: Scleractinian, ISRS 2002 European Meeting, Cambridge, England 2002.
32. Szmant AM. Reproductive ecology of Caribbean reef corals, Coral Reefs 1986; 5: 43-54.

33. Duerden JE. West Indian madreporarian polyps, Memoirs of the National Academy of Sciences 1902; 8: 401-597.

34. Van Veghel MLJ. Reproductive characteristics of the polymorphic Caribbean reef building coral Montastrea annularis. I. Gametogenesis and spawning behavior, Marine Ecology Progress Series 1994; 109: 209-219.

35. Fenner D. New observations on the stony coral (Scleractinia, Milleporidae, and Stylasteridae) species of Belize (Central America) and Cozumel (Mexico), Bulletin of Marine Science 1999; 64: 143-154.

36. de Graaf M, Geertjes GJ, Videler JJ. Observations on spawning of scleractinian corals and other invertebrates on the reefs of Bonaire (Netherlands Antilles, Caribbean), Bulletin of Marine Science 1999; 64: 189-194.

37. Vermeij MJA, Sampayo E, Bröker K, Bak RPM. Variation in planulae release of closely related coral species, Marine Ecology Progress Series 2003; 247: 75-84.

38. Pizarro V. Dinámica poblacional de corales cerebro (Scleractinia: Faviidae) en la Isla de San Andrés, Caribe suroccidental: una aproximación, Instituto de Estudios Caribeños. Universidad Nacional de Colombia, San Andrés Isla, 2002, 62p.

39. Pizarro V, Polania J, Thomason JC. Recruitment and juvenile survivorship of brain corals at San Andres Island, Western Caribbean Sea, Cahiers de Biologie Marine 2007; 48 (2): 113-119.

40. López T, Navas R, Gil-Agudelo D. Corales escleractínios juveniles como evidencia del mantenimiento de las formaciones coralinas en el Archipiélago de las Islas del Rosario, in INVEMAR, (Eds). Informe del Estado de los Ambientes Marinos y Costeros de Colombia: Año 2006. Serie de publicaciones periódicas/INVEMAR, Santa Marta, 2007, p. 73-77.

41. Pizarro V, Herrón P, Thomason J. An improved technique for rearing Montastraea faveolata embryos and larvae, Coral Reefs 2006; 25 (3): 360-360.

42. Dueñas LF. Estructura de la comunidad y distribución de corales escleractinios juveniles y adultos de la Bahía de Chengue, Parque Tayrona (Caribe colombiano), Facultad de Ciencias Pontificia Universidad Javeriana, Bogotá, 2005, 99p.

43. Bernal JK. Relación entre condiciones físicas y biológicas del microhábitad y la presencia de juveniles de corales hermatípicos en ambientes oceánicos y de la plataforma continental del Caribe Colombiano, Facultad de Ciencias. Pontificia Universidad Javeriana, Bogotá, 2005, 116p. 
44. Rodríguez J. Estructura de la comunidad de juveniles y adultos de coral a través de un gradiente de profundidad en un área aisturbada, punta de Betín Santa Marta, Caribe Colombiano, Facultad de Ciencias. Pontificia Universidad Javeriana, Bogotá, 2005, 80p.

45. Ordoñez MS. Variación en la estructura de la comunidad de corales hermatípicos juveniles entre arrecifes continentales (Isla Grande e Isla Fuerte) y Oceanía (San Andrés y Providencia), Caribe Colombiano, Facultad de Ciencias. Pontificia Universidad de los Andes, Bogotá, 2004, 119p.

46. Cárdenas F. Distribución vertical, composición, riqueza densidad de corales hermatípicos juveniles en un arrecife de Isla Grande, Caribe Colombiano, Facultad de Ciencias. Pontificia Universidad Javeriana, Bogotá, 2004,

47. Sepúlveda M. Distribución vertical, composición, riqueza densidad de corales hermatípicos juveniles en un arrecife de Isla Fuerte, Caribe Colombiano, Facultad de Ciencias. Pontificia Universidad Javeriana, Bogotá, 2004,

48. Vidal A. Distribución vertical, composición, riqueza y densidad de corales hermatípicos juveniles en San Andrés Isla, Caribe Colombiano, Facultad de Ciencias. Pontificia Universidad Javeriana, Bogotá, 2004, 90p.

49. Villamil C. Distribución vertical y estructura de la comunidad de corales hermatípicos en la isla de providencia, caribe colombiano, Facultad de Estudios Ambientales y Rurales. Pontificia Universidad Javeriana, Bogotá, 2006, 75p.

50. López T. Abundancia, distribución y composición taxonómica de corales escleractinios juveniles en formaciones coralinas del Archipiélago de las Islas del Rosario, Caribe colombiano, Facultad de Biología Marina. Universidad de Bogotá Jorge Tadeo Lozano, Santa Marta, Colombia, 2007, 109p.

51. Martínez S, Acosta A. Cambio temporal en la estructura de la comunidad coralina del área de Santa Marta - Parque Nacional Natural Tayrona (Caribe Colombiano), Boletín de Investigaciones Marinas y Costeras 2005; 34: 161-191.

52. Babcock RC. Comparative demography of three species of scleractinian corals using age- and size-dependent classification, Ecological Monographs 1991; 61 (3): 225244

53. Dueñas LF, Montenegro J, Acosta A, Cárdenas F, Sepúlveda M, Vidal A, Villamil C, Guide to Scleractinian coral recruits from the Caribbean, ed., Pontificia Universidad Javeriana, Unidad de Ecología y Sistemática, Facultad de Ciencias. INVEMAR Serie de Documentos Generales No. 42. XPRESS Estudio Gráfico y Digital, Bogotá D.C. Colombia 2010,
54. Lozano-Cortéz D, Zapata FA. Distribución de tallas de fragmentos de corales del género Pocillopora en el arrecife coralino de La Azufrada, Isla Gorgona, Libro de resúmenes extendidos, XIV Seminario Nacional de Ciencias y Tecnologías del Mar 2010: 233-237.

55. Burt J, Bartholomew A, P.F. S. Benthic development on large-scale engineered reefs: a comparison of communities among breakwaters of different age and natural reefs, Ecological Engineering 2010; 37: 191-198.

56. Acosta A, Bernal K, Jaramillo-González J, MariñoCorrea D, Ordoñez M, Camacho J, Ruíz M, Alvarez D. Investigaciones desde la perspectiva de la conectividad y el reclutamiento coralino para el entendimiento del estado, estructura y dinámica de los arrecifes coralinos (Caribe), in INVEMAR, (Eds). Informe del Estado de los Ambientes Marinos y Costeros en Colombia 2005. Serie de Publicaciones Periódicas No. 8, Santa Marta, Colombia, 2006, p. 96-108.

57. Nystrom M, Folke C, Moberg F. Coral Reef Disturbance and Resilience in a Human-Dominated Environment, Trends in Ecology \& Evolution 2000; 15 (10): 413-417.

58. Harriott VJ. Coral recruitment at a high latitude pacific site: a comparison with Atlantic reefs, Bulletin of Marine Science 1999; 65 (3): 881-891.

59. Connell JH, Hughes TP, Wallace CC, Tanner JE, Harms KE, Kerr AM. A long-term study of competition and diversity of corals, Ecological Monographs 2004; 74 (2): 179-210.

60. Connell JH, Hughes TP, Wallace CC. A 30-Year study of coral abundance, recruitment, and disturbance at sevral scales in space and time, Ecological Monographs 1997; 67 (4): 461-488.

61. Fisk DA, Harriott VJ. Spatial and temporal variation in coral recruitment on the Great Barrier Reef: Implications for dispersal hypotheses, Marine Biology 1990; 107: 485490.

62. Sammarco PW. Geographically specific recruitment and postsettlement mortality as influences on coral communities: The cross-continental shelf experiment, Limnology and Oceanography 1991; 36: 496-514.

63. Harriott VJ, Banks SA. Recruitment of scleractinian corals in the Solitary Islands marine reserve, a high latitude coral-dominated community in eastern Australia, Marine Ecology Progress Series 1995; 123: 155-161.

64. Dunstan PK, Johnson CR. Spatio-temporal variation in coral recruitment at different scales on Heron Reef,southern Great Barrier Reef, Coral Reefs 1998; 17: 71-81.

65. Rogers CS, Fitz HC, Gilnack M, Beets J, Hardin J. Scleractinian coral recruitment at Salt River submarine canyon, St. Croix, U.S. Virgin Islands, Coral Reefs 1984; 3: 69-76. 
66. Smith SR. Patterns of coral settlement,recruitment and juvenile mortality with depth at Conch Reef, Florida, Proceedings of the 8th International Coral Reef Symposium 1997; 2: 1197-1202.

67. Connell JH. Diversity in tropical rain forest and coral reefs, Science 1978; 199: 1302-1310.

68. Harriott V, Fisk DA. Recruitment patterns of scleractinian corals: a study of three reefs, Australian Journal of Marine \& Freshwater Research 1988; 39: 409-416.

69. Geister J. The influence of wave exposure on ecological zonation of Caribbean coral reefs, Preceedings, 3rd Int'l Coral Reef Symposium, Miami Fl. 1977: 23-29.

70. Done TJ. Patterns in the distribution of coral communities across the central Great Barrier Reef, Coral Reefs 1982; 1: 95-107.

71. SHEPPARD CE. Coral population on reef slopes and their major controls, Marine Ecology Progress Series 1982; 7: 83-115.

72. Babcock RC, Mundy CN. Coral recruitment: consequences of settlement choice for early growth and survivorship in two scleractinians, Journal Experimental Marine Biology and Ecology 1996; 206: 179-201.

73. Mundy C, Babcock RC. Are vertical distribution patterns of scleractinian corals maintained by pre- or post-settlement processes? A case study of three contrasting species, Marine Ecology Progress Series 2000; 198: 109-119.

74. Carlon DB. Production and supply of larvae as determinants of zonation in a brooding tropical coral, Journal Experimental Marine Biology and Ecology 2002; 268: $33-46$.

75. Zlatarski VN, Martinez-Estalella N. Les Scléractiniaires de Cuba avec des données sur les organismes associés, Editions de l'Académie bulgare des Sciences, Sofia 1982: 472.

76. Guzmán H, Guevara C. Arrecifes coralinos de bocas del Toro, Panamá: IV. Distribución, estructura y estado de conservación de los arrecifes continentales de Península Valiente, Revista de Biología Tropical 2001; 49 (1): 53-66.

77. Morse DE, Hooker N, Morse ANC, Jensen RA. Control of larval metamorphosis and recruitment in sympatric agariciid corals, Journal of Experimental Marine Biology and Ecology 1988; 116: 193-217.

78. Sammarco P. Coral recruitment across the central Great Barrier Reef: a preliminary report, in Baker J, Carter R, Sammarco P, Stark K, (Eds). Proceedings of the Great Barrier Reef Conference. James Cook University Press, Townsville. Australia, 1983, p. 245-251.

79. Hurtado N, Pizarro V, Sanjuan-Muñoz A, García-Llano CF. Estado actual de las poblaciones del coral hermatípico Colpophyllia natans (Houtuyn, 1772) en el área de Santa Marta y el Parque Nacional Natural Tayrona, Caribe colombiano, in INVEMAR-ACIMAR, (Eds). Libro de resúmenes extendidos XIV Seminario Nacional de Ciencias y Tecnologías del Mar (SENALMAR): Serie de Publicaciones Especiales del INVEMAR No. 21. Santa Marta, 2010, p. 187-192.

80. Wittenberg M, Hunte W. Effects of eutrophication and sedimentation on juvenile corals, Marine Biology 1992; 112 (1): 131-138.

81. Montenegro J, Acosta A, Havistat 2008 V.1.0. Programa para inferir uso y preferencia de hábitat, ed., Unesis, Departamento de Biología, Facultad de Ciencias, Pontificia Universidad Javeriana, Bogotá, Colombia 2008,

82. Montenegro J, Acosta A. Habitat preference of zoantharia genera depends on host sponge morphology., Universitas Scientiarum 2010; 15 (2): 110-121.

83. Iwao K, Fujisawa T, Hatta M. A cnidarian neuropeptide of the GLWamide family induces metamorphosis of reefbuilding corals in the genus Acropora, Coral Reefs 2002; 21 (2): 127-129. 